\title{
Von Willebrand factor and platelet adhesiveness
}

\author{
DOMINIQUE MEYER AND MARIE-JOSÉ LARRIEU \\ From the Department of Coagulation, Institut de Recherches sur les Maladies du Sang, \\ Hôpital St Louis, Paris
}

SYNOPSIS A modification of Salzman's method has been used in an attempt to provide $\stackrel{\circ}{工}$ an assay in vitro for the von Willebrand factor. Platelet adhesiveness was increased in von $\vec{\nabla}$ Willebrand's disease by previously coating the beads with normal or haemophilic plasma or cryoprecipitate, whereas von Willebrand plasma had no corrective effect. Antihaemophilic $\overrightarrow{\vec{\theta}}$ factor (AHF) concentrates were studied in the same way and results compared with experiments in vivo.

Platelet adhesiveness to glass beads as described by Salzman (1963) is a valuable test in the diagnosis of von Willebrand's disease (Strauss and Bloom, 1965; Meyer, Larrieu, Maroteaux, and Caen, 1967b), although not specific for the disorder.

As suggested by the results of infusion in vivo of normal plasma or fraction I-0, both the decreased platelet adhesiveness (Salzman, 1963) and the long bleeding time (Nilsson, Blomback, Jorges, Blomback, and Johanson, 1957) may be related to the deficiency of an, as yet unidentified, plasma factor, called 'vascular factor' or 'Willebrand factor'. To examine this possibility further, a modification of Salzman's method has been used in an attempt to provide an in-vitro assay for the Willebrand factor. Data obtained were compared with results of trials in vivo in von Willebrand patients.

\section{Material and Methods}

Platelet adhesiveness was measured using Salzman's method (1963). The time taken for the blood to pass through the glass bead column was kept constant (45 seconds) and results were discarded if the volume of blood collected was not between 5.5 and $6.5 \mathrm{ml}$. Owing to the slight modifications of the original method (Meyer and Larrieu, 1967a), platelet adhesiveness in the control varies from 20 to $50 \%$. In 28 patients with von Willebrand's disease the index value $\stackrel{\odot}{\stackrel{\odot}{\odot}}$ was consistently abnormal, usually below $10 \%$ on repeated examinations.

The following modifications were used for the assay in vitro: buffer or test material (plasma, cryoprecipitate, or AHF concentrates) was drawn into the glass bead column at a constant? rate $\left(3 \mathrm{ml}\right.$ in 90 seconds). The coated glass bead $\frac{0}{3}$ column was left for 10 minutes at $20^{\circ} \mathrm{C}$, after. which the test material or buffer was removed $\frac{O}{2}$ by suction. Platelet adhesiveness was then assessed in a patient with von Willebrand's disease in the usual way, using the coated glass $\rightarrow$ bead column. A control glass bead column prepared under the same conditions was used for the assay of the amount of protein remaining in the glass bead column by the Folin-Ciocalteu method (Lowry, Rosenbrough, Farr, and Randall, $\omega$ 1951). The material used, including glass beads, polyvinyl tube, and connectors, was rinsed inco $10 \mathrm{ml}$ of either distilled water or $\mathrm{NaOH} 1 \mathrm{~N}$. The results were expressed as the final amount ${ }^{+}$ of protein per millilitre of blood passing through $\frac{0}{0}$ the glass beads during the test.

Platelet counts were performed in double $\stackrel{\mathbb{\Omega}}{\stackrel{\Omega}{\Omega}}$ blind by phase-contrast microscopy, using $1 \% \mathbb{\mathscr { Q }}$ ammonium oxalate solution as diluent.

Citrated platelet-poor plasma $(0.38 \%$ final concentration) was obtained from normal, haemophilic, or von Willebrand patients. Received for publication 21 August 1969. 


\begin{tabular}{lllc}
\hline & Cryoprecipitate & \multicolumn{2}{c}{ AHF Concentrates } \\
\cline { 3 - 4 } & & $\begin{array}{l}\text { Intermediate } \\
\text { Purity }\end{array}$ & $\begin{array}{c}\text { High } \\
\text { Purity }\end{array}$ \\
\hline Protein $(\mathrm{g} / 100 \mathrm{ml})$ & $3 \cdot 1$ & $5 \cdot 3$ & $2 \cdot 0$ \\
$\begin{array}{l}\text { Fibrinogen } \\
(\mathrm{g} / 100 \mathrm{ml})\end{array}$ & $0 \cdot 42$ & $0 \cdot 78$ & $0 \cdot 16$ \\
Factor VIII (\%) & 560 & 700 & 2,100 \\
\hline
\end{tabular}

Table I Mean factor VIII, fibrinogen, and protein concentration of plasma fractions

\begin{tabular}{llll}
\hline & \multicolumn{3}{l}{ Platelet } \\
\cline { 2 - 4 } & Normal & Haemopheness Index $(\%)$ \\
\hline \multirow{2}{*}{ Plasma } & $18^{1}$ & 15 & Von Willebrand \\
\hline \multirow{3}{*}{ Cryoprecipitate } & $(9-28)^{2}$ & $(10-20)$ & 2 \\
& 25 & 21 & $(0-6)$ \\
& $(13-38)$ & $(14-32)$ & $(0-2)$ \\
\hline
\end{tabular}

Table II Effect of plasma and cryoprecipitate from normal and haemophiliac or von Willebrand patients on platelet adhesiveness in von Willebrand's disease

'Mean

${ }^{2}$ Extreme values

\begin{tabular}{|c|c|c|c|c|c|c|}
\hline & $\begin{array}{l}\text { Control } \\
\text { (standard } \\
\text { column) }\end{array}$ & Buffer & Control & $\begin{array}{l}\text { Citrated } \\
\text { Buffer }\end{array}$ & Control & $\begin{array}{l}\text { Citrated } \\
\text { Normal } \\
\text { Plasma }\end{array}$ \\
\hline $\begin{array}{l}\text { Platelet } \\
\text { adhesiveness } \\
\text { index }(\%)\end{array}$ & 28 & 27 & 26 & $18 \cdot 3$ & $25 \cdot 2$ & $27 \cdot 2$ \\
\hline
\end{tabular}

Table III Effect of citrate on platelet adhesiveness (mean of six experiments)

Plasmas for the assay in vitro of Willebrand factor were used either immediately after collection or quickly frozen in dry ice-alcohol and kept at $-20^{\circ} \mathrm{C}$.

Cryoprecipitate was prepared from control or patients' plasmas according to the method of Hershgold, Pool, and Pappenhagen (1966). The mean protein, fibrinogen, and factor VIII concentrations are listed in Table I.

Intermediate and high purity AHF concentrates (Johnson, Newman, Howell, and Puszkin, 1967) were kindly provided through the courtesy of Dr Alan Johnson (Table I). For the experiments in vivo, the amount of protein infused was $200 \mathrm{mg} / \mathrm{kg}$ body weight for the intermediate purity AHF and $20 \mathrm{mg} / \mathrm{kg}$ for the high purity concentrate.

Albumin and gamma globulin solutions were made up of NBC crystalline human albumin and NBC human fraction II.
Michaelis buffer was at $\mathbf{p H} \mathbf{7 \cdot 3 5}$.

Citrated buffer was prepared by adding 1 part $\cong$ of $3.8 \%$ sodium citrate to 5 parts of buffer.

\section{Results}

EFFECT OF NORMAL, HAEMOPHILIC, OR WILLEBRAND PLASMA

All the patients with von Willebrand's disease $\stackrel{\odot}{\circ}$ used for the assay in vitro had a platelet adhesiveness index below $5 \%$.

A definite increase in platelet adhesiveness was. observed with normal (mean $18 \%$ ) or haemo- $\vec{\omega}$ philic (mean $15 \%$ ) plasma, although the results were variable, but coating the beads with? Willebrand plasma had no corrective effecti (Table II).

The effect of citrate on platelet adhesiveness was elucidated in control subjects, using glass $\infty$ bead columns previously incubated with normal윽 citrated plasma or citrated buffer. Platelet adhesiveness in the control was only slightly? modified by normal citrated plasma (Table III) whereas it was consistently decreased in the $\vec{\varphi}$ presence of citrated buffer.

EFFECT OF NORMAL, HAEMOPHILIC, OR WILLEBRAND CRYO PRECIPITATE Cryoprecipitates prepared from fresh normal orष्ठ haemophilic plasma increased platelet adhesiveness to a mean of $25 \%$ and $21 \%$ (Table II) whereas cryoprecipitate from Willebrand plasma was ineffective.

\section{EFFECT OF AHF CONCENTRATES}

Intermedite and high purity AHF concentrates were tested in the same way and results were compared with purified albumin or gamma globulin solutions, using the same protein con-은 centration. Both AHF concentrates completely $>$ normalized platelet adhesiveness which was not? modified in the presence of albumin or gammaN globulin (Table IV).

\section{CONCENTRATION OF THE PROTEINS}

COATING THE GLASS BEADS

This concentration was measured for the different materials tested. The final protein concentration per millilitre of blood passing through ${ }_{\bar{O}}^{0}$ the glass beads was compared with the mean $\overrightarrow{\mathbb{D}}$

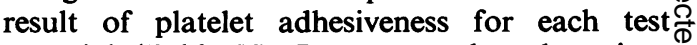

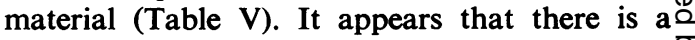
progressive increase in the platelet adhesiveness? index in von Willebrand's disease with the 8 different materials, despite a progressive decrease in the final protein concentration in the test: system. 


\begin{tabular}{|c|c|c|c|c|c|}
\hline \multirow[t]{3}{*}{ Case No. } & \multirow{3}{*}{$\begin{array}{l}\text { Control } \\
\text { (standard } \\
\text { column) }\end{array}$} & \multicolumn{4}{|c|}{ Platelet Adhesiveness Index $(\%)$} \\
\hline & & \multicolumn{2}{|c|}{ AHF Concentrates } & \multirow{2}{*}{$\begin{array}{l}\text { Albumin } \\
(25 \mathrm{mg} / \mathrm{ml})\end{array}$} & \multirow{2}{*}{$\begin{array}{l}\gamma \text { Globulin } \\
(20 \mathrm{mg} / \mathrm{ml})\end{array}$} \\
\hline & & $\begin{array}{l}\text { Intermediate } \\
\text { Purity } \\
(50 \mathrm{mg} / \mathrm{ml})\end{array}$ & $\begin{array}{l}\text { High Purity } \\
(20 \mathrm{mg} / \mathrm{ml})\end{array}$ & & \\
\hline 1 & 3 & 53 & & & 3 \\
\hline 2 & 1.5 & 39 & & & \\
\hline 3 & 0 & 41 & & & \\
\hline 4 & 2 & 17 & 37 & $4 \cdot 5$ & \\
\hline 5 & 0 & & & 3 & 0 \\
\hline 6 & 3 & 29 & 25 & & \\
\hline 7 & 4 & & 24 & & \\
\hline 8 & 0 & & 27 & & \\
\hline 9 & 4.5 & & 24 & & \\
\hline
\end{tabular}

Table IV 'Effect of AHF concentrates on platelet adhesiveness in von Willebrand's disease

\begin{tabular}{lll}
\hline Test Material & $\begin{array}{l}\text { Platelet } \\
\text { Adhesiveness } \\
\text { Index }(\text { mean }) \\
(\%)\end{array}$ & $\begin{array}{l}\text { Final Protein } \\
\text { Concentration } \\
(\text { mean }) \\
(\mu \mathrm{g} / \text { ml blood })\end{array}$ \\
\hline Normal plasma & 18 & 832 \\
Haemophilic plasma & 15 & 772 \\
Normal cryoprecipitate & 25 & 361 \\
Intermediate purity AHF & $35 \cdot 8$ & 310 \\
High purity AHF & 27.4 & 74 \\
\hline
\end{tabular}

Table V Comparison of platelet adhesiveness and protein concentration coating the glass bead column

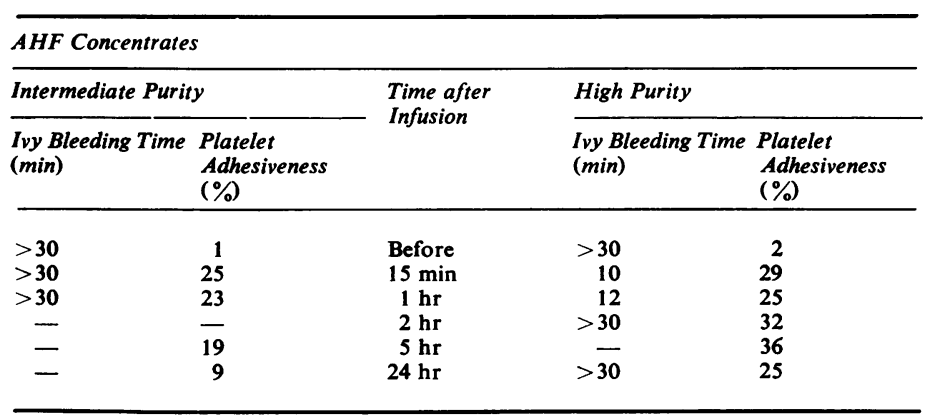

Table VI Infusion of AHF concentrates in a case of a severe form of von Willebrand's disease

\begin{tabular}{lll}
\hline Time & $\begin{array}{l}\text { Ivy Bleeding Time } \\
(\text { min })\end{array}$ & $\begin{array}{l}\text { Platelet Adhesiveness } \\
(\%)\end{array}$ \\
\hline & & \\
Before & $>30$ & 4 \\
$15 \mathrm{~min}$ & 29 & 17 \\
$1 \mathrm{hr}$ & 28 & 21 \\
$2 \mathrm{hr}$ & $>30$ & 12 \\
\hline
\end{tabular}

Table VII Infusion of high purity AHF concentrates to a case of a moderate form of von Willebrand's disease
CORRELATION WITH EXPERIMENTS

IN VIVO

Antihaemophilic factor concentrates (intermed iate and high purity material) were infused ine five patients with von Willebrand's disease Intermediate purity AHF resulted in a complete correction of the platelet adhesiveness index ands of the Duke bleeding time, lasting for five hourso but Ivy bleeding time was not modified (Table VI) $\frac{\bar{\sigma}}{\sigma}$ The effect of high purity material was even bette in the same patient with a very severe form of von Willebrand's disease (Table VI) as the increase in the platelet adhesiveness index lasted? for 24 hours and the Ivy bleeding time was normalized for one hour. Results with the same material in another patient with a moderate form of von Willebrand's disease are reporte⿳亠丷厂 in Table VII. Bleeding time according to Ivy' criteria was shortened (28 minutes) althoug $f^{\omega}$ not normalized, and platelet adhesiveness rosผ to $21 \%$ after one hour (Table VII).

With both AHF concentrates, factor VIIb increased as previously described (Cornu, Larrieu, Caen, and Bernard, 1963).

\section{Discussion}

With respect to certain important technica conditions, platelet adhesiveness to glass beadळ on whole blood as measured by Salzman (1963\% is a useful test in the diagnosis of patients wit 18 von Willebrand's disease and of their relative (Larrieu, Caen, Meyer, Vainer, Sultan, an $\Phi$ Bernard, 1968). Among those technical con ditions, the transit speed of blood passing througr the glass bead column is the most importanf to consider, as O'Brien and Heywood (1967. have shown that only a high flow rate wilo demonstrate an abnormality in von Willebrand's. disease. Using a different method in vitro some authors (Zucker, 1963; Salzman and Britten 1964) have proved the correction of platele adhesiveness in von Willebrand's disease witt normal citrated (Zucker, 1963) or heparinized. (Salzman and Britten, 1964) plasma. In theser methods, blood from patients with von Wille brand's disease was previously mixed with norma足 plasma and then passed through a glass bead column. The coating of glass beads with plasmar before the test was suggested by Vigliano an Horowitz (1966) for the study of the inhibitor $\Phi^{\circ}$ effect of IgA myeloma plasma on platelet adhesiveness.

Plasma proteins, and especially fibrinogen greatly influence the interaction of platelets with glass surfaces (Packham, Evans, Glynn, an $\$$ Mustard, 1969) and adsorption of proteins op the glass beads may be an important factog in the measurement of platelet adhesivenes by Salzman's method. However, the effect of platelet adhesiveness in von Willebrand's disease. 
reported in our experiments does not seem to be explained by a non-specific coating of proteins on the glass beads, since Willebrand plasma or cryoprecipitate had no corrective effect. Besides, there is no correlation between the fibrinogen content of the plasma fractions and the increase in platelet adhesiveness. Moreover, our results obtained in vitro correlate well with experiments in vivo (Larrieu et al, 1968).

In summary, studies in vitro indicate the existence in normal and haemophilic plasma of a factor, transferable to glass beads and capable of inducing retention of Willebrand platelets by such beads. These results correlating experiments in vivo lend further support to the existence of a plasmatic factor deficiency which is responsible for the decreased platelet adhesiveness characteristic of this disorder.

This work was supported in part by a grant from INSERM. The assistance of $\mathrm{B}$. Obert is gratefully acknowledged, and the courtesy of Dr Alan Johnson, American Red Cross Research Laboratory, New York, in providing AHF concentrates.

\section{References}

Cornu, P., Larrieu, M. J., Caen, J. P., and Bernard, J. (1963). Transfusion studies in von Willebrand's disease: effect on bleeding time and factor VIII. Brit. J. Haemat., 9, 189-202.

Hershgold, E. J., Pool, J. G., and Pappenhagen, A. R. (1966). The potent antihemophilic globulin concentrate derived from a cold insoluble fraction of human plasma. J. Lab. clin. Med., 67, 23-32.
Johnson, A. J., Newman, J., Howell, M. B., and Puszkin, Sc (1967). Purification of antihemophilic factor (AHF) for clinical and experimental use. Thrombos. Diathes. haemorrh
(Stuttg.), Suppl. 377-381.

Larrieu, M. J., Caen, J. P., Meyer, D. O., Vainer, H., Sultan, Y. and Bernard, J. (1968). Congenital bleeding disorders with bleeding, time and normal platelet count. II. voro Willebrand's disease. Amer. J. Med., 45, 354-372.

Lowry, O. H., Rosebrough, N. J., Farr, A. L., and Randall, R. J? (1951). Protein measurement with the Folin phenof? reagent. J. biol. Chem., 193, 265-275.

Meyer, D., and Larrieu, M. J. (1967). L'analyse des fonctions plaquettaires: mesure de l'adhésivité des plaquettes au verre sur sang total (méthode de Salzman). Rev. franç Étud. clin. biol., 12, 736-739.

Meyer, D., and Larrieu, M. J. (1967b). Biological findings in尺 von Willebrand's pedigrees: implications for inheritance, J. clin. Path. 20, 190-194.

Nilsson, I. M., Blombäck, M., Jorpes, E., Blombäck, B., and Johansson, S. A. (1957). von Willebrand's disease and its' correction with human plasma fraction I-O. Acta med. $\overrightarrow{\vec{\omega}}$ scand., 159, 179-188.

O'Brien, J. R., and Heywood, J. B. (1967). Some interactions between human platelets and glass: von Willebrand's disease compared with normal. J. clin Path., 20, 56-64.

Packham, M. A., Evans, G., Glynn, M. F., and Mustard, J. F. స్ (1969). The effect of plasma proteins on the interaction of platelets with glass surfaces. J. Lab. clin.Med., 73, 686-697.

Salzman, E. W. (1963). Measurement of platelet adhesiveness: N a simple in vitro technique demonstrating an abnormality $\infty$ in von Willebrand's disease. J. Lab. clin. Med., 62, 724-음 735 .

Salzman, E. W., and Britten, A. (1964). In vitro correction of defective platelet adhesiveness in von Willebrand's disease. $D$ (Abstr.). Fed. Proc., 23, 239.

Strauss, H. S., and Bloom, G. E. (1965), von Willebrand's disease: use of a platelet-adhesiveness test in diagnosis $\overrightarrow{0}$ and family investigation. New Engl. J. Med., 273, 171-181.

Vigliano, E., and Horowitz, H. (1966). Information Exchange. Group, 97.

Zucker, M. B. (1963). In vitro abnurmality of the blood in vono Willebrand's disease correctable by normal plasma. Nature (Lond.), 197, 601-602. 